\title{
A microplate enzyme-immunoassay for toxoplasma antibody
}

A. VOLLER ${ }^{1}$, D. E. BIDWELL ${ }^{2}$, A. BARTLETT ${ }^{2}$, D. G. FLECK ${ }^{3}$, M. PERKINS $^{3}$, AND B. OLADEHIN ${ }^{3}$

From the Department of Clinical Tropical Medicine, London School of Hygiene and Tropical Medicine, Keppel Street, London WC1', Nuffield Institute of Comparative Medicine, The Zoological Society of London, Regent's Park, London NW1 ${ }^{2}$, and Public Health Laboratory, St. George's Hospital, London SWI

SYNOPSIS A new test for the detection and measurement of toxoplasma antibody is described. Teșf sera are reacted with antigen-sensitized wells in micro-haemagglutination plates. Any attached anti body is shown by the addition of an enzyme-labelled antiglobulin followed by assay of the enzyme reaction with its substrate. The test is easy to carry out on a large scale, and there is a positive correla tion between the results and dye test and haemagglutination test titres.

The diagnosis of toxoplasmosis is not easy and is usually based on the critical assessment of one or more serological tests. The dye test (Sabin and Feldman, 1948), indirect immunofluorescence (Kelen et al, 1962), and passive haemagglutination (Jacobs and Lunde, 1975) are the tests most frequently employed. Karim and Ludlam (1975) have recently devised a system of integrating the results of several tests to give more precise information on the stage of the disease. There is clearly scope for other methods and, since enzyme immunoassays have given promising results in two other protozoal parasitic infections, Chagas disease (Voller et al, 1975a) and malaria (Voller et al, 1975b), we thought it worthwhile to investigate their potential in toxoplasmosis.

\section{Material and Methods}

\section{ANTIGEN}

Toxoplasma gondii organisms obtained from peritoneal exudates of infected mice were ruptured by freeze-thawing once followed by sonication for 20 seconds at $4^{\circ} \mathrm{C}$. The cell debris was removed by centrifugation at $10000 \mathrm{~g}$ for 30 minutes, and the supernatant fluid (the stock antigen) was stored in aliquots at $-70^{\circ} \mathrm{C}$ until used.

SERA

One hundred and ninety-eight sera submitted to the Public Health Laboratory, St. George's Hospital,
London were tested by the dye test (Sabin and Feldman, 1948), by passive haemagglutination (Jacobs and Lunde, 1975), and by the microenzigme linked immunosorbent assay (MICRO-ELISA) ifeso cribed below. These sera came from clinicil suspected cases of toxoplasmosis and 16 of then with dye test titres over $>1 / 1024$, were from typicon lymphadenopathy cases.

\section{MICRO-ENZYME-LINKED IMMUNOSORBENT}

ASSAY

The enzyme-linked immunosorbent assay (ELISA of Engvall and Perlmann (1972) with the modifica: tion (MICRO-ELISA) of Voller et al (1975a) was used. The principle of the assay is described i figure 1. For toxoplasmosis the test was carried out as follows:

1 The wells in microhaemagglutination plates (COOKE MICROTITER M29 AR ${ }^{1}$ ) were serf sitized with the toxoplasma antigen, diluted its $0.05 \mathrm{M}$ carbonate buffer, pH 9.6, overnight a政 $+4^{\circ} \mathrm{C}$. The plates were then given three washess each of 3 minutes in phosphate buffered saline (PBS) containing $0.05 \%$ Tween 20 and were shaken dry.

$20.3 \mathrm{ml}$ of the diluted serum was added to each we and incubated for 2 hours at room temperatureo The plates were washed as before in PBS/Tween and were shaken dry.

$30.3 \mathrm{ml}$ of the diluted antiglobulin conjugate was added to each well and incubated for 3 hours

${ }^{1}$ Dynatech Laboratories Ltd 

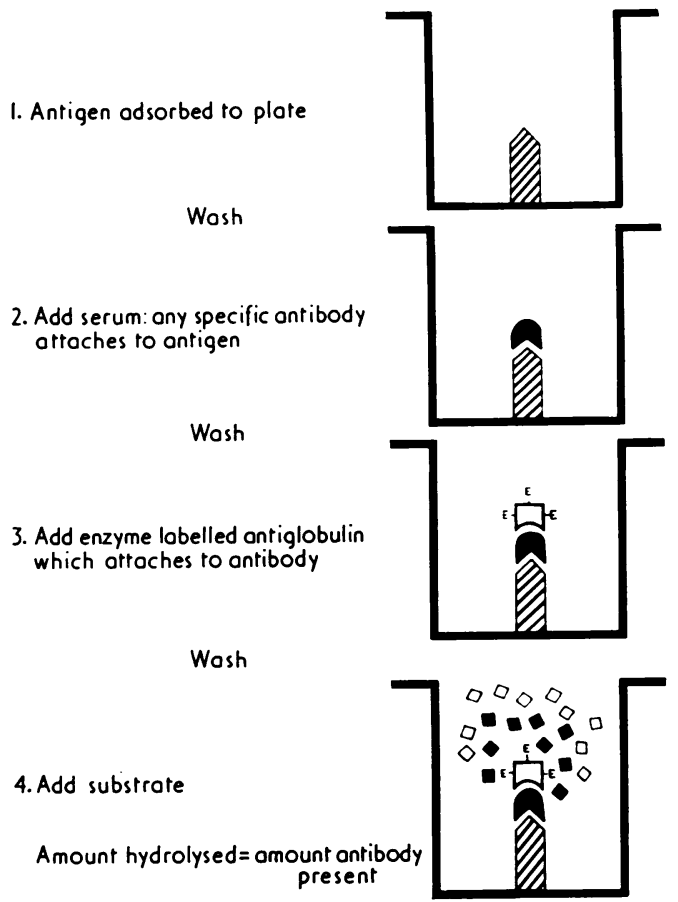

Fig 1 Principle of the MICRO-ELISA technique.

at room temperature after which the plates were again washed and shaken dry. (This conjugate consisted of rabbit antihuman globulin labelled with alkaline phosphatase (Engvall and Perlmann, 1972).)

$40.3 \mathrm{ml}$ of the enzyme substrate was added (substrate $=1 \mathrm{mg}$ p-nitrophenylphosphate per $\mathrm{ml}$ diethanolamine buffer, $\mathrm{pH} 9 \cdot 8$, containing 0.5 $\mathrm{mmol}: \mathrm{MgCl}_{2}$ ). The enzymic hydrolysis of substrate was stopped after 30 minutes by the addition of $0.05 \mathrm{ml} \mathrm{2M} \mathrm{NaOH}$.

The results are expressed as the absorbance at $\mathbf{4 0 0}$ $\mathrm{nm}$ which was determined in a spectrophotometer with a $1 \mathrm{~cm}$ light path.

\section{PRELIMINARY TITRATIONS}

The antigen preparation was titrated in a chequerboard fashion against a positive reference serum sample and against a negative reference sample. An antigen dilution of 1:200 gave the biggest difference between the positive and negative sera, and this was used in all subsequent tests. The positive and negative reference antisera were similarly titrated, and the biggest difference between them was at a serum dilution of 1:200 so this was used in the tests.
Results

Tests on a small batch of sera indicated that an absorbance value of 0.3 or less usually corresponded with negative dye test and IHA results. Accordingly, in the test reported here all absorbance values ( $\equiv$ MICRO-ELISA value) over 0.3 have been considered positive.

In table I the relationship of positive and negative MICRO-ELISA values to dye test titres is shown. Table II shows the relationship of positive and negative MICRO-ELISA values to IHA titres.

It can be seen that virtually all sera with dye test titres of $1 / 64$ or atove, or IHA titres of $1 / 40$ or above, have positive MICRO-ELISA values. Between $10 \%$ and $20 \%$ of the sera with negative dye test or IHA had positive MICRO-ELISA values. Comparison of positive and negative results obtained by IHA or dye test showed a similar discrepancy of $10-20 \%$ between the tests.

The mean MICRO-ELISA values for the different dye test titre groups and IHA titre groups are given inffigure 2. The positive correlation between dye-test, IHA, and mean MICRO-ELISA values is clear. The distribution of MICRO-ELISA values for each dye test titre group and each IHA titre group are shown in figs 3 and 4 respectively.

\begin{tabular}{lllll}
\hline $\begin{array}{l}\text { Dye Test Titre } \\
\text { Group }\end{array}$ & $\begin{array}{l}\text { No. of Sera in } \\
\text { Group }\end{array}$ & \multicolumn{4}{c}{ MICRO-ELISA Results } \\
\cline { 3 - 5 } \cline { 3 - 4 } & & Negative & Positive & $\%$ Positive \\
\hline$<16$ & 91 & 78 & 13 & 14 \\
$16 / 32$ & 17 & 13 & 4 & 23 \\
$64 / 128$ & 29 & 5 & 24 & 83 \\
$256 / 512$ & 34 & 2 & 32 & 94 \\
1024 and above & 27 & 1 & 26 & 96 \\
\hline
\end{tabular}

Table I Relationship of toxoplasma dye test results to MICRO-ELISA results (the latter are grouped as positive $(>0 \cdot 3)$ or negative $(<0 \cdot 3))$

\begin{tabular}{ccccc}
\hline IHA Titre Group & $\begin{array}{l}\text { No. of Sera in } \\
\text { Group }\end{array}$ & \multicolumn{3}{c}{ MICRO-ELISA Results } \\
\cline { 3 - 5 } & & Negative & Cositive & $\%$ Positive \\
\hline$<40$ & 106 & 87 & 19 & 18 \\
$40 / 80$ & 39 & 9 & 30 & 77 \\
$160 / 320$ & 31 & 2 & 29 & 94 \\
$640 / 1280$ & 16 & 1 & 15 & 94 \\
Above 1280 & 6 & 0 & 6 & 100 \\
\hline
\end{tabular}

Table II Relationship of toxoplasma passive haemagglutination results to MICRO-ELISA results (the latter are grouped as positive $(>0 \cdot 3)$ or negative $(<0 \cdot 3))$ 

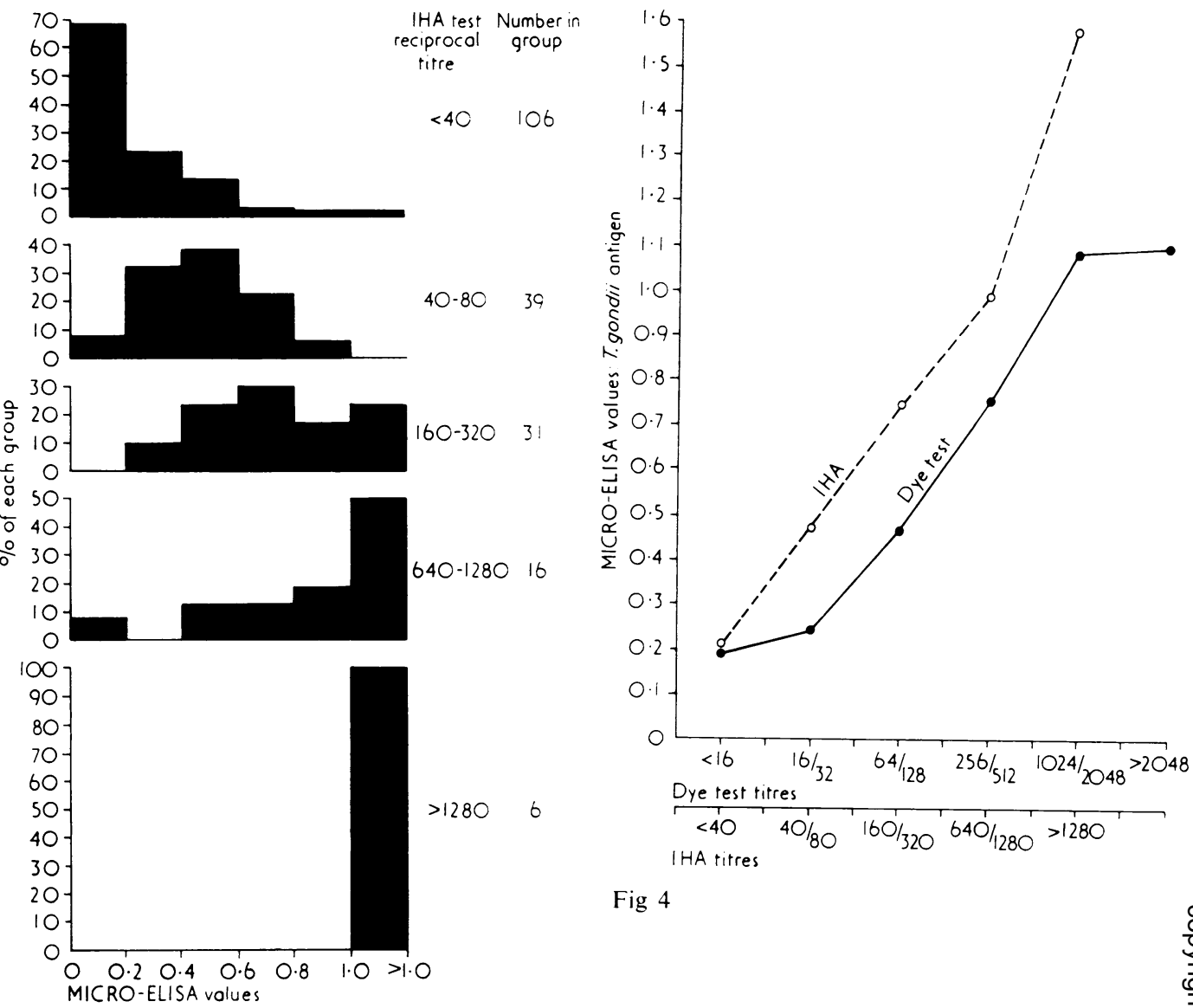

Fig 4

Fig 2

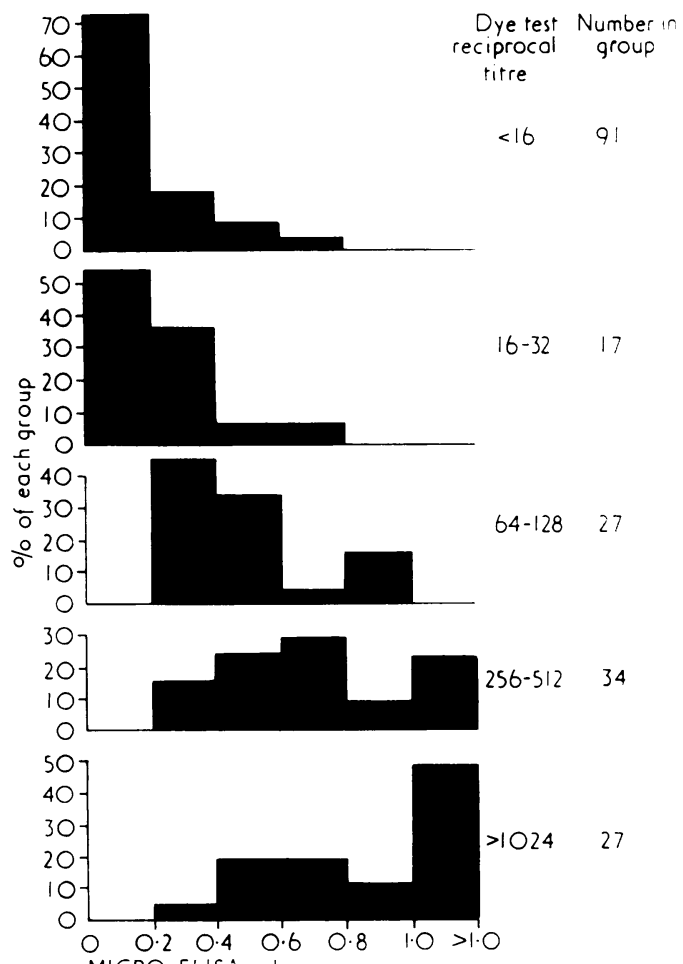

Fig 2 Mean MICRO-ELISA values for the sera grouped according to IHA titres (dotted line) or dye test titres (solid line).

Fig 3 Distribution of MICRO-ELISA values of sera grouped according to dye test titres.

Fig 4 Distribution of MICRO-ELISA values of sera grouped according to IHA titres. 


\section{Discussion}

Enzyme immunoassays are inherently attractive as they are sensitive, give only objective results, and are suitable for large-scale automation. The reagents used are stable and, although enzymes are expensive, only minute quantities are used so that the cost per assay is low. There are, however, difficulties in standardizing the test, and small changes in procedure may lead to large differences in end results. The present methods for preparing the conjugates are considered inadequate as only a small proportion of the globulin is labelled, and unless the preparation is carefully fractionated unlabelled globulin and free enzyme are present.

However, in spite of these difficulties the preliminary results on toxoplasma suggest that enzyme immunoassays may take their place alongside other established methods. The results show that, overall, there is a positive correlation between dye-test and MICRO-ELISA values and IHA and MICROELISA values, although there are a few notable exceptions where high titred sera in one test gave low values in the other. The correlation between IHA and MICRO-ELISA values was better than that between dye-test and MICRO-ELISA.

Perhaps a more serious disadvantage which emerges is that the ELISA, carried out as described, does not adequately discriminate between sera with medium dye-test titres (eg, 256-512) and those with very high titres (eg, over 1024). This distinction is clinically important. Possibly the use of purified antigens and better conjugates will enable this differentiation to be made. In the present study only an anti-immunoglobulin conjugate has been employed, but there is no reason why class specific im- munoglobulin conjugates should not be used, in which case it would be possible to detect specific IgM toxoplasma antibodies.

These preliminary studies indicate the potential of the enzyme immunoassay method for diagnosis of toxoplasma infection, and we feel that they justify further investigation.

The financial assistance of the World Health Organization and Medical Research Council of Great Britain made these studies possible. We are particularly indebted to Dr N. Kent of WHO for his personal interest in encouraging the development of enzyme immunoassays.

\section{References}

Engvall, E. and Perlmann, P. (1972). Enzyme-linked immunosorbent assay (ELISA). III. Quantitation of specific antibodies by enzyme-labelled anti-immunoglobulin in antigencoated tubes. J. Immunol., 109, 129-135.

Jacobs, L. and Lunde, M. N. (1975). A haemagglutination test for toxoplasmosis. J. Parasit., 43, 308-314.

Karim, K. A. and Ludlam, G. B. (1975). The relationship and significance of antibody titres as determined by various serological methods in glandular and ocular toxoplasmosis. J. clin. Path., 28, 42-49.

Kelen, A. E., Ayllon-Leindl, L., and Labzoffsky, N. A. (1962). Indirect fluorescent antibody method in serodiagnosis of toxoplasmosis. Canad. J. Microbiol., 8, 545554.

Sabin, A. B. and Feldman, H. A. (1948). Dyes as microchemical indicators of a new immunity phenomenon affecting a protozoan parasite (Toxoplasma). Science, 108, 660663.

Voller, A., Draper, C. C., Bidwell, D. E., and Bartlett, A. (1975a). Microplate enzyme-linked immunosorbent assay for Chagas disease. Lancet, 1, 426-429.

Voller, A., Huldt, G., Thors, C., and Engvall, E. (1975b). New serological test for malaria antibodies. Brit. med. J., 1, 659-661. 